\title{
USE OF CT FOR ANALYSIS OF THE VERTEBRAL FORAMEN IN THE HOSPITAL OF QUERÉTARO
}

\author{
USO DE TC PARA ANÁLISE DO FORAME VERTEBRAL NO HOSPITAL \\ DE QUERETARO
}

\section{USO DE TC PARA ANÁLISIS DEL FORAMEN VERTEBRAL EN EL HOSPITAL} DE QUERÉTARO

Jesús Cisneros Lámbarri ${ }^{1}$, José Tovar López ${ }^{1}$, José Grimaldo Tellez ${ }^{1}$, Haro Sandoval ${ }^{1}$

1. Hospital General de Querétaro, Traumatoloy and Orthopedics Service, Spine Department, Santiago de Querétaro, Qro., Mexico.

\begin{abstract}
Objective: To determine the morphology of the vertebral foramen and its distance to the midline. Methods: Twenty cervical CT scans from the radiographic record of 12 men and 8 women, 18 to 74 years old, of C1 to C6 segments were evaluated, measuring the foramen diameter and its distance to the midline. We look for anomalies of vertebral foramen morphology, using Philips Ingenuity CT equipment with Philips IntelliSpace Portal software. Results: The mean age was 47 years; the segment with the most anomalies was $\mathrm{C} 1$, with $10 \%$ (increase in foramen diameter), followed by C2 and C6, with 5\% (vertebral foramen hypotrophy); the mean diameter of the C1 to C6 segment was 6.081 $\mathrm{mm}$, and the median distance from the midline to the vertebral foramen of C2 to C6 was $13.215 \mathrm{~mm}$. The largest diameter of the vertebral foramen was $\mathrm{C} 2$, with a mean of $6.67 \mathrm{~mm}$ and the smallest was $\mathrm{C} 4$, with a mean of $5.75 \mathrm{~mm}$; the greatest distance from the midline to the vertebral foramen was $\mathrm{C} 1$, with a mean of $22.59 \mathrm{~mm}$ and the shortest was $\mathrm{C} 4$, with a mean of $12.13 \mathrm{~mm}$. Conclusions: The mean diameter of the vertebral foramen and its distance to the midline was determined, setting a safety region for procedures. In our city, there is no study that determines the means of the vertebral foramina diameters, the distance from the midline and its anomalies. It is necessary to rely on CT scans and to make a preoperative plan to avoid complications associated with morphological alterations.
\end{abstract}

Keywords: Spinal canal; Spine/anatomy \& histology; Vertebral artery; Tomography.

\section{RESUMO}

Objetivo: Determinar a morfologia do forame vertebral e sua distância da linha mediana. Métodos: Foram avaliadas 20 tomografias cervicais do arquivo radiográfico de 12 homens e 8 mulheres, de 18 a 74 anos de idade, dos segmentos C1 a C6, fazendo a medição do diâmetro do forame e de sua distância até a linha mediana. Buscaram-se as anomalias da morfologia do forame vertebral, usando um equipamento Philips Ingenuity CT com o software Philips IntelliSpace Portal. Resultados: A média de idade foi 47 anos; o segmento com mais anomalias foi C1, com 10\% (aumento do diâmetro do forame), seguido por C2 e C6, com 5\% (hipotrofia do forame vertebral); o diâmetro médio do segmento C1 a C6 foi $6,081 \mathrm{~mm}$ e a distância média da linha mediana até o forame vertebral de C2 a C6 foi 13,215 mm. O maior diâmetro do forame vertebral foi C2, com média de 6,67 mm e o menor foi C4, com média de 5,75 mm; a maior distância da linha mediana até o forame vertebral foi a de C1, com média de 22,59 mm e a menor foi em C4, com média de 12,13 mm. Conclusões: Foi determinada a média do diâmetro do forame vertebral e sua distância até a linha mediana, estabelecendo-se uma região de segurança para procedimentos. Em nossa cidade, não há um estudo que determine a médias dos diâmetros do forame vertebral, a distância da linha mediana e suas anomalias. É preciso contar com a tomografia e fazer um plano pré-operatório para evitar as complicações associadas às alterações morfológicas.

Descritores: Canal vertebral; Coluna vertebral/anatomia \& histologia; Artéria vertebral; Tomografia.

\section{RESUMEN}

Objetivo: Determinar la morfología del foramen vertebral y su distancia de la línea media. Métodos: Se evaluaron 20 tomografías cervicales, del archivo radiográfico de 12 hombres y 8 mujeres, de 18 a 74 años de edad, del segmento C1 a C6, realizando la medición del diámetro del foramen, y su distancia de la línea media. Se buscaron las anomalías morfológicas del foramen vertebral, usando un equipo Philips Ingenuity CT y software Philips IntelliSpace Portal. Resultados: La edad promedio fue de 47 años; el segmento con más anomalías fue C1, con 10\% (aumento del diámetro del foramen), seguido de C2 y C6 con 5\% (hipotrofia del foramen vertebral); el promedio del diámetro del segmento C1 a C6 fue de 6,081 mm y el promedio de distancia de la línea media al foramen vertebral de C2 a C6 fue 13,215 mm. El mayor diámetro del foramen vertebral fue en C2, con promedio de 6,67 mm y el menor fue en C4 con promedio de 5,75 mm; la mayor distancia de línea media al foramen vertebral correspondió en C1 con promedio de 22,59 mm y la menor fue en C4 con promedio de 12,13 mm. Conclusiones: Se determinó el promedio del diámetro del foramen vertebral y su distancia a la línea media, estableciendo una zona de seguridad para procedimientos. En nuestra ciudad no existe un estudio que determine promedios del diámetro del foramen vertebral, la distancia desde la línea media y sus anomalías. Es preciso contar con tomografía y hacer un plan preoperatorio para evitar las complicaciones asociadas con alteraciones morfológicas.

Descriptores: Conducto vertebral; Columna vertebral/anatomía \& histología; Arteria vertebral; Tomografía. 


\section{INTRODUCTION}

Currently, at the Hospital General de Querétaro, anterior cervical approach procedures are performed and, although it is rare in this type of procedure, the consequences can be catastrophic, since they are associated with complications such as fistulas, pseudo-aneurisms, hemorrhages, thrombosis, cerebral ischemia, embolism, infection, and death. ${ }^{1}$

The lesion rates reported in the United States range from $0.3 \%$ to $0.5 \% .^{2-5}$ In posterior approach surgeries, the rates reported are variable and depend on the instrumentation technique used. They range from $4.1 \%$ to $8.2 \%$ for transarticular screws (C1-C2), and there are no lesions reported for subaxial lateral mass screws. ${ }^{6}$

Currently, morphometric evaluations of the cervical pedicles have already been reported in studies involving small numbers of vertebrae in cadavers, as well as in older adults, who, because of their condition, present degenerative changes. ${ }^{7}$

Previous studies include patients with degenerative symptoms of the cervical spine or are specifically focused on the Asian population.

We believe that such data will provide the surgery with an improved understanding of pedicle anatomy and improve decision-making.

Therefore, the purpose of this review is to understand the morphology of the vertebral foramen through operative planning using computed axial tomography, which improves the understanding of the specific morphology of each patient, benefiting preoperative decision making and reducing the risk of a lesion of the vertebral artery.

\section{METHODS}

For this study, 20 simple cervical tomographies from the digital radiography archive were evaluated.

Patients with a history of chronic or acute traumatic cervical abnormalities, symptoms suggesting degenerative or inflammatory disease, evidence of infectious or neoplastic conditions, and congenital malformations of the cervical spine were included.

Patients with incomplete or not assessable tomographies were excluded.

An informed consent form was obtained from all the study participants and the study was approved by the Institutional Review Board as registration number (304/17-10-20 VI).

PHILIPS Ingenuity CT equipment and IntelliSpacePortal software were used for all patients, with $3.0 \mathrm{~mm}$ helical scans of the cervical spine and reconstruction intervals of $1.5 \mathrm{~mm}$. The scans were performed with the patients in a supine position and the neck in a neutral position. The morphological characteristics were obtained for cervical vertebrae $\mathrm{C} 1$ to $\mathrm{C} 6$. A total of 12 men and 8 women ranging from 18 to 74 years of age were analyzed.

The program measured the diameter of the vertebral foramen and the distance from the foramen to the midline. We looked for anomalies in the morphology of the vertebral foramen (VF). (Figure 1)

The mean age was 47 years. The segment where the most anomalies were found was $\mathrm{C} 1$, with $10 \%$ (increase in the diameter of the

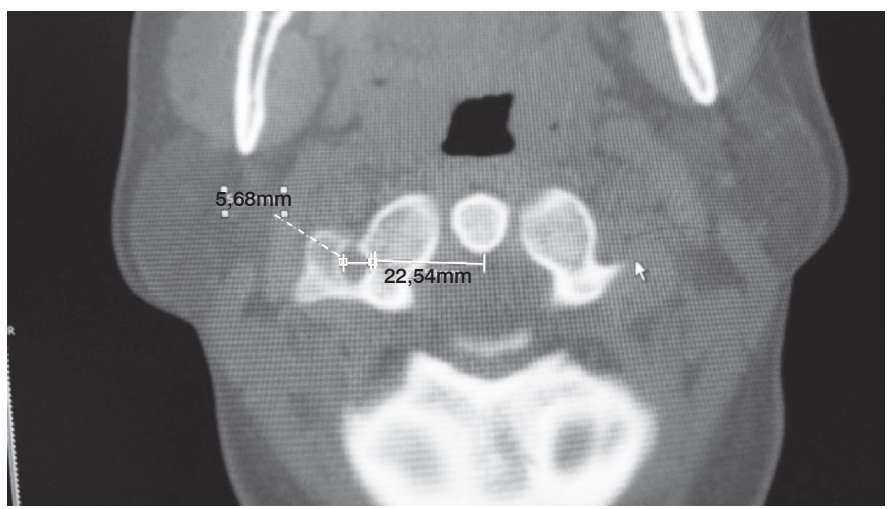

Figure 1. Example of an axial section of $\mathrm{C} 1$, showing the measuring of the diameter of the vertebral foramen and the distance from the foramen to the midline. ${ }^{8}$ foramen), (Figure 2), followed by C2 and C6, each with 5\% (hypotrophy of the vertebral foramen).

The mean diameter of the vertebral foramen of the $\mathrm{C} 1$ to $\mathrm{C} 6$ segment was 6.081 and the mean distance from the midline to the vertebral foramen of C2 to C6 was $13.215 \mathrm{~mm}$. (Table 1)

The vertebral foramen of $\mathrm{C} 2$ had the greatest mean diameter at $6.67 \mathrm{~mm}$ and of $\mathrm{C} 4$, the smallest mean diameter at $5.75 \mathrm{~mm}$. C1 had the greatest mean distance from the midline to the vertebral foramen at $22.59 \mathrm{~mm}$ and $\mathrm{C} 4$ had the smallest mean distance at $12.13 \mathrm{~mm}$. (Table 1)

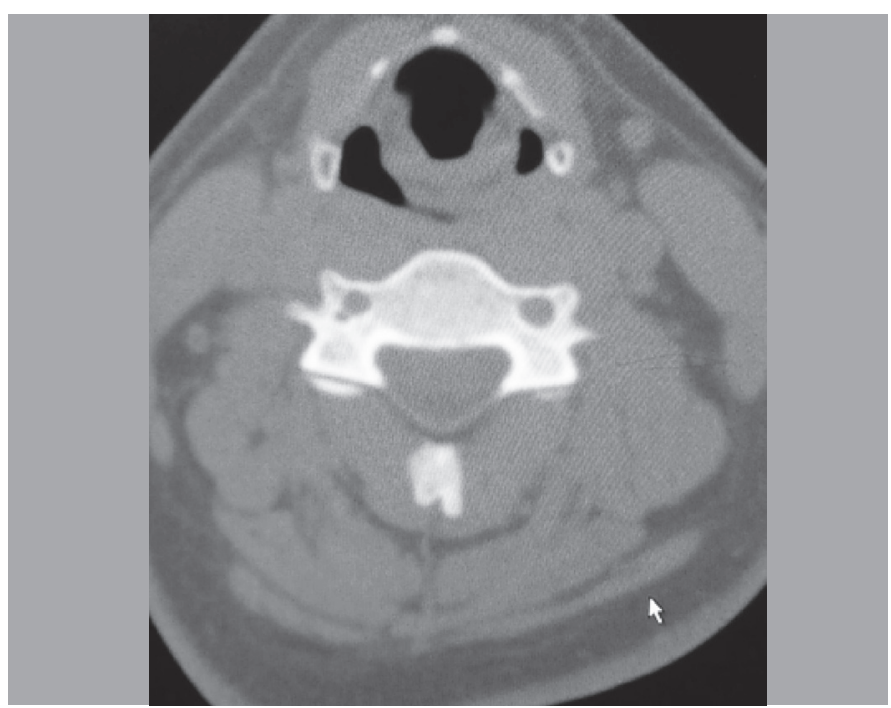

Figure 2. Example of a cervical vertebral foramen deformity. ${ }^{8}$

Table 1. This table shows the mean diameter of the vertebral foramen at the midline, and the distance from the vertebral foramen to the midline. (Source: Department of Imageology, Digital Radiography Archive of the Hospital General de Querétaro).

\begin{tabular}{c|c|c}
\hline & Mean VF Diam & $\begin{array}{c}\text { Mean Distance from } \\
\text { VF to the midline }\end{array}$ \\
\hline c1 & 6.061578947 & 22.59368421 \\
\hline c2 & 6.674210526 & 14.55631579 \\
\hline c3 & 5.913052632 & 12.49315789 \\
\hline c4 & 5.754210526 & 12.13052632 \\
\hline c5 & 6.305789474 & 12.43789474 \\
\hline c6 & 5.778947368 & 14.46105263 \\
\hline Mean foramen & 6.081298246 & 13.21578947 \\
\hline
\end{tabular}

\section{DISCUSSION}

In this study, the mean diameter of the vertebral foramen and the mean distance from the foramen to the midline were determined, establishing a safety zone for procedures. No study exists for our population that determines the mean of the vertebral foramen and the midline, or their anomalies. It is necessary to have a tomography and to conduct preoperative planning to avoid possible complications associated with morphological changes.

\section{CONCLUSION}

At present, there are no studies to determine which is the morphological change most common in the vertebral foramen, in our study it is a decrease in the diameter of the foramen, which could affect the diameter of the vertebral artery, so that a lesion of the foramen and consequently of the contralateral side of said anomaly 
could have catastrophic consequences, as previously mentioned. It was also determined that the mean distance from the vertebral foramen to the midline in the corresponding bodies from C2 to C6 is $13.12 \mathrm{~mm}$, which could be used as a safety range when working with the drill in this area during anterior approach surgery. (Figure 3)

\section{ACKNOWLEDGEMENTS}

To all the personnel of the Hospital General de Querétaro, to the department of imageology, to professors Arturo García Balderas, Nicolás Camacho, Mario Alberto García, Juan Manuel Martinez, and Eusebio Ortega for providing and facilitating access to the studies.

All authors declare no potential conflict of interest related to this article.

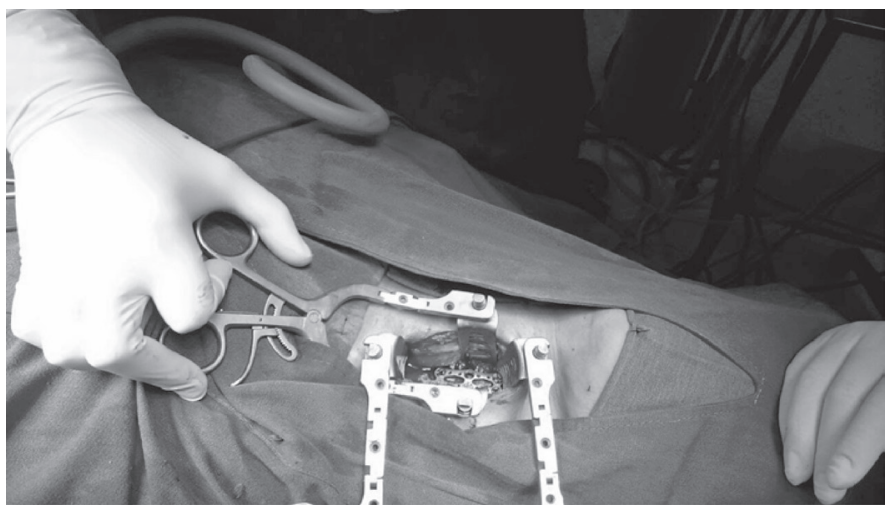

Figure 3. Example of anterior approach cervical decompression surgery, after placement of the plate. ${ }^{9}$

CONTRIBUTION OF THE AUTHORS: Each author made significant individual contributions to this manuscript. JCL wrote the abstract, provided translation, wrote the Methods section, and contributed to the Discussion section. JTL prepared the statistical tables, wrote the Results section, and contributed to the Discussion section. JGT prepared the Conclusion section based on the Results and HS contributed to the Discussion section.

\section{REFERENCES}

1. Peng CW, Chou BT, Bendo JA, Spivak JM. Vertebral artery injury in cervical spine surgery: anatomical considerations, management, and preventive measures. Spine J. 2009;9(1):70-6.

2. Daentzer D, Deinsberger W, Böker DK. Vertebral artery complications in anterior approaches to the cervical spine: report of two cases and review of literature. SurgNeurol. 2003;59(4):300-9.

3. Golfinos JG, Dickman CA, Zabramski JM, Sonntag VK, Spetzler RF. Repair of vertebral artery injury during anterior cervical decompression. Spine (PhilaPa 1976). 1994:19(22):2552-6

4. Smith MD, Emery SE, Dudley A, Murray KJ, Leventhal M. Vertebral artery injury during anterior decompression of the cervical spine. A retrospective review of ten patients. $J$
Bone Joint Surg Br. 1993:75(3):410-5.

5. Burke JP, Gerszten PC, Welch WC. Latrogenic vertebral artery injury during anterior cervical spine surgery. Spine J. 2005;5(5):508-14.

6. Abumi K, Shono Y, Ito M, Taneichi H, Kotani Y, Kaneda K. Complications of pedicle screw fixation in reconstructive surgery of the cervical spine. Spine (PhilaPa 1976). 2000;25(8):962-9.

7. Rao RD, Marawar SV, Stemper BD, Yoganandan N, Shender BS. Computerized tomographic morphometric analysis of subaxial cervical spinepedicles in young asymptomatic volunteers. J Bone Joint Surg Am. 2008:90(9):1914-21.

8. Archivo Radiológico Hospital General de Querétaro.

9. Archivo Fotográfico Departamento de Columna Hospital General de Querétaro. 